\title{
THE DIRECTIVE 2016/97 ON INSURANCE DISTRIBUTION (IDD) AND PRIVATE INTERNATIONAL LAW
}

\author{
Mariusz Fras*
}

\begin{abstract}
Clear normative grounds for the information obligation are visible in the Directive (EU) 2016/97 of the European Parliament and of the Council of 20 January 2016 on insurance distribution (hereinafter: IDD). One of the challenges before insurance law is to answer the question of whether and how one should sanction violations of disclosure obligations resulting in the absence of the desired insurance protection. In this aspect important legal problem is the law applicable to the assessment of liability for violation of disclosure obligations by the insurer.

The second important problem is the law applicable to the assessment of liability for violation of disclosure obligations by third parties vis-a-vis the insurer. Some remarks concerning jurisdiction in matters relating to the loss of chance to become insured have different practical implications.
\end{abstract}

Key words: IDD, the loss of chance to become insured, information obligations, the law applicable, the third party of insurance

\section{INTRODUCTION}

The insurance contract is generally qualified as a contract of utmost confidence (contractus uberrimae fides) based on the good faith principle. This principle should be understood as a requirement to take into account

* Associate Professor Hab., PhD, The Faculty of Law and Administration, University of Silesia. 
the interests of the counterparty at the stage of concluding and performing the contract ${ }^{1}$.

One of the basic manifestations of good faith in the insurance contract is the existence of pre-contractual disclosure obligations ${ }^{2}$. It must be emphasized that such obligations are mutual. On one hand, the party seeking insurance protection is imposed with the obligation to provide the insurer with the information relevant to the assessment of risk ${ }^{3}$, on the other one, the insurer is expected to notify the policyholder about the circumstances affecting the decision on the conclusion of the insurance contract ${ }^{4}$.

The widely understood information obligation may take three forms, namely the duty to provide guidance, duty to draw attention and duty to give advices.

Clear normative grounds for the information obligation are visible in the Directive (EU) 2016/97 of the European Parliament and of the

1 See F. Reichert-Facilides, Contract Law: General Aspects In: H. Heiss, M. Lakhan, eds., Principles of European Insurance Contract Law: A Model Optional Instrument, München 2011, p. 144-146.

2 T. Pfeiffer, New Mechanisms for Concluding Contracts, In: R. Schulze (ed.), New Features in Contract Law, München 2007, 162.

3 More in M. Fras, In: System Prawa Handlowego. Międzynarodowe Prawo Handlowe, vol. 9, ed. W. Popiołek, Warszawa 2013, 582. The principle of good faith as a source of the obligation of declaring risk is described in B. Kucharski, Naruszenie powinności deklaracji jako podstawa odmowy wypłaty odszkodowania ubezpieczeniowego, Acta Universitatis Lodziensis. Folia Iuridica 2013, No. 72, 25-28.

4 R. Merkin, Colinvaux's Law of Insurance, London 1997, 125.

5 More in M. Fras, Odpowiedzialność brokera ubezpieczeniowego za niewykonanie lub nienależyte wykonanie zobowiązania: rozważania na tle orzecznictwa Sądu Najwyższego, PA 2009, No. 3, 3 et seq. The provision of $\$ 6(1)$ first sentence of the German Act on the insurance contract (Versicherungsvertragsgesetz, BGBl. I, S. 2631) sets out that the insurer is obliged to ask the policyholder about his expectations and needs when this is justified by difficulties in the evaluation of the offered insurance or the character of the policyholder or his situation and, taking into consideration the due proportion between the cost of consultancy and amount of premium, to provide the policyholder with advice and justify that advice. See Art. L 112-2 of the Insurance Code (Code des assurances, Journal Officiel de la République française, 1978, 1088, modifié). The direction in which the principle under that provision was developed by the French Court of Cassation is analyzed in more detail in J. Bigot, La responsabilité civile des sociétés d'assurance à l'égard des assures en droit français, In: Mélanges Roger O. Dalcq, Bruxelles 1994, 25 and the case-law cited therein. 
Council of 20 January 2016 on insurance distribution (hereinafter: IDD) ${ }^{6}$, which is intended to ensure more transparency on the part of insurance distributors and improvement of the terms of business activities pursued by such distributors. Under the provision of Art. 20 IDD, "[p]rior to the conclusion of an insurance contract, the insurance distributor shall specify, on the basis of information obtained from the customer, the demands and the needs of that customer [...] Any contract proposed shall be consistent with the customer's insurance demands and needs." The demands-andneeds test becomes a new pre-contractual obligation imposed on insurance distributors.

In the IDD's preamble, Recital 44 reads that: "In order to avoid cases of mis-selling, the sale of insurance products should always be accompanied by a demands-and-needs test on the basis of information obtained from the customer. Any insurance product proposed to the customer should always be consistent with the customer's demands and needs and be presented in a comprehensible form to allow that customer to make an informed decision." It should be emphasized that the overarching objective of the IDD is to ensure, among others, protection to customers, which in turn has very strong ties to the issue of mis-selling prevention.

Expansion in the content of the disclosure obligation is in line with a general trend to protect persons considered to be the weaker party of an obligational relationship? .

6 OJ EU L 26 of 2 February 2016.

7 The significance of pre-contractual disclosure obligations in the insurance contract is also accentuated in the case-law of the ECJ. In the judgment of 9 December 2013 in the case C-209/12 Walter Endress v. Allianz Lebensversicherungs AG, Monitor Prawniczy 2014, No. 3, 120, the ECJ expressed the opinion that the model assumptions on the sanctions for violation of disclosure obligations at the pre-contractual stage, which were developed for the purpose of protecting consumers who conclude off-premises contracts, match the needs of ensuring protection to policyholders. In justification of that position, it was indicated that "insurance contracts are financial products which are complex from the legal perspective, which may essentially differ depending on the insurer being the offeror and may give rise to significant and potential long-term financial obligations, [and at the same time] the policyholder has a weaker position in relation to the insurer, and his situation is analogous to the one of a consumer concluding an off-premises contract." This conclusion is material inasmuch as it refers to one of most rigorous, from entrepreneurs' perspective, models of consumer protection in the entire acquis, which is discussed in more detail in B. Gnela, 
One of the key problems in the insurance market is purchase by customers of insurance products that do not match their needs ${ }^{8}$. Inadequacy of an insurance product leads, in particular, to the following consequences: a) absence of insurance protection in respect of specific risks or incomplete (partial) insurance protection in respect of a specific risk; b) excessive (unnecessary) insurance protection.

Moreover, it seems that within the first category it is necessary to distinguish between two situations:

1) the policyholder wrongly assumes that a specific risk known to him is covered by insurance protection on account of the conclusion of a specific contract. Cases falling under this category form a vast majority of factual situations examined in judicial practice?;

2) the policyholder does not know that there exists insurance protection against a specific risk or does not realize the expedience of concluding particular insurance.

Inadequate (incomplete) insurance protection results in encumbrance of the policyholder's finances because it is the policyholder and not the insurer to incur the financial consequences of an insurance accident.

The second category (excessive insurance protection) refers to another issue: the policyholder incurs the costs of insurance protection against risks to which, generally (in theory or practice), he is not exposed. In other words, the insurer offers to the policyholder an insurance product that does not match his needs. Although situations falling under this category do not expose insurance customers to an acute (unexpected) necessity to incur financial consequences of an insurance accident (loss) from their own funds, they result in economically unjustified investments in needless insurance protection.

Umowa konsumencka w polskim prawie cywilnym i prywatnym międzynarodowym, Warszawa 2013, 210 et seq.

8 Cf. G. McMeel, The FSA's insurance conduct of business regime: a revolution in (consumer) insurance law?, Lloyd's Maritime and Commercial Law Quarterly 2005, No. 2, 186, 187.

9 P. Tereszkiewicz, Obowiązki informacyjne w umowach o usługi finansowe, Warszawa 2015,346 . 


\section{THE CONCEPT AND ESSENCE OF LOSS OF CHANCE TO BECOME INSURED}

One of the challenges before insurance law is to answer the question of whether and how one should sanction violations of disclosure obligations resulting in the absence of the desired insurance protection.

Depending on the position taken in this matter by the law designated as applicable, inadequacy of insurance protection caused by a violation of one of the three forms of disclosure obligation may lead to the policyholder being given the right to terminate the unfavorable contract ${ }^{10}$, the insurer being deprived of the possibility to rely on the contractual clauses responsible for the inadequacy of insurance protection ${ }^{11}$ or the insurer's compensatory liability for a so-called loss of chance to become insured.

Especially extensive investigations on the loss of chance to become insured (perte de chance de s'assurer, perte de chance de souscrire une assurance) were conducted in French case-law in the context of group insurance. It is indicated that violation of disclosure obligations may result in compensatory liability when the party seeking insurance protection, despite sensible evaluation of the situation, cannot enjoy a benefit of the insurance contract which he could have expected in case of materialization of the risk against which that party such sought to insure himself ${ }^{12}$.

10 P. Tereszkiewicz, Obowiązki informacyjne ....., 346.

11 D. Krajeski, In: Droit de la responsabilité et des contrats, ed. P. Le Tourneau, Paris 2012, 985 .

12 See the judgment of the Court of Cassation of 31 January 2012, Cass. com., 31 janvier 2012, $\mathrm{n}^{\circ}$ 11-11700; the judgment of the Court of Cassation of 15 December 2011, Civ.2e, 15 décembre 2011, $\mathrm{n}^{\circ} 10-23889$. The conception of the loss of chance to become insured (perte de chance de s'assurer) was commented on by the Court of Cassation also in another context in the judgment of 25 January 2012, Cass. soc., 25 janvier 2012, $\mathrm{n}^{\circ} 11-11.374$. In that case, the Court of Cassation found that an employer, by omitting to notify an employee that it does not pay premium for retirement insurance and by omitting to present to the employee a full picture of his retirement situation, deprived the employee of a chance of insurance since the employer precluded him from making a reasonable decision on the voluntary payment of premium in the social security system. 
In common law countries, analogous claims are asserted against insurance brokers in connection with the loss of chance to obtain insurance protection (the chance of being covered by insurance) ${ }^{13}$.

However, the status of the so-called loss of chance in the regime of compensatory liability is highly arguable. Results of comparative law research allow to draw the conclusion that certain legal systems approve of that conception (Belgium, Spain, France, Greece, Ireland, Italy, Luxemburg, Holland, United Kingdom) ${ }^{14}$, whereas others to a lesser (Austria, Denmark, Finland, Sweden) or greater extent (Germany, Portugal) question its admissibility ${ }^{15}$. It should be added that a part of them analyze the compensation for a lost chance in terms of causal link, while others associate it with the concept of damage ${ }^{16}$, and even in such legal systems there are doubts as to the specification of the amount of the financial benefit payable to the injured party ${ }^{17}$.

13 A. Kramer, The Law of Contract Damages, Oxford 2014, 280-281.

14 In the legal systems which are supportive of this conception, it is assumed, in principle, that a "loss of chance" may amount to a damage when as a result of specific acts or omissions a probability is nullified of the occurrence of an event favorable to the injured party even though the materialization of chance is never certain. Apart from the classical preconditions to compensatory liability, namely fault and causal link, it is required that the damage manifest in the loss of chance be real and serious. More in J.L. Fagnart, La perte d'une chance ou la valeur de l'incertain, In: C. Devoet, J.L. Fagnart, C. Paris eds., La réparation du dommage. Question particulières, Louvain-la-Neuve 2006, s. 77-80; see S. Martens, R. Zimmermann, In: Digest of European Tort Law. Volume 2: Essential Cases on Damage, eds. B. Winiger, H. Koziol, B.A. Koch, R. Zimmermann, Berlin 2011, 1075 at seq. and the case-law analyzed therein.

15 J.M. Binon, La réparation de la perte d'une chance dans la jurisprudence européenne: une question de chance?, In: Liber Amicorum Jean-Luc Fagnart, Bruxelles 2008, 380-381.

16 E. Bagińska, Odpowiedzialność deliktowa w razie niepewności związku przyczynowego. Studium prawnoporównawcze, Warszawa 2013, 278 i n. It should be noted that discrepancies in this regard can also be found within a specific legal system. More in the context of insurance in J. Bigot, La responsabilité..., 32 and the literature cited therein.

17 One may distinguish between two principal models. The former consists in adjudication ex aequo et bono. The other, referred to as the method of proportional compensation, boils down to the calculation of compensation taking into account the loss of chance as expressed in percentage, J.M. Binon, La réparation..., 381. 
It seems that according to the position taken in this regard by Polish law, "loss of chance to become insured" may be analyzed in terms of a damage manifest in the loss of profits (lucrum cessans) ${ }^{18}$, which differs from the legally irrelevant potential loss of profit by a high degree of probability ${ }^{19}$. It may be considered in the violation of disclosure obligations, as a special instance of culpa in contrahendo, is not remediable only within the scope of negative contractual interest.

The situation is complicated in the insurance context by the fact that such services are, in principle, "standardized." This problem can be analyzed both in terms of the existence of a causal link and at the stage of determining the size of the damage. It may not be excluded that on the insurance market no services are to be found which would correspond to the expectations of the party seeking insurance protection. The insurance adjusted to the needs of the policyholder may also involve the necessity to pay a higher premium which the policyholder would not decide (or would not be able) to pay ${ }^{20}$. However, if the absence of protection derives from the insurer's reliance on a contractual clause limiting the insurer's scope of liability, the amount of compensation should be decreased by the amount of the premium which the injured party would have had to pay to obtain the desired insurance protection ${ }^{21}$.

18 See E. Bagińska, Odpowiedzialność..., 239 et seq..; otherwise in the judgment of the Supreme Court of 31 January 2002, IV CKN 642/00, Legalis No. 278037, in whose justification an opinion was expressed that " "loss of chance» may imply both an actual damage and loss of profits (lucrum cessans)".

19 See M. Nesterowicz, Utrata szansy wyleczenia lub przeżycia w prawie francuskim, PiP 2010, No. 3, 42.

20 In the judgment of 31 May 2011, the Court of Cassation shared the opinion of the Court of II Instance which dismissed the compensatory claim for a loss of chance to become insured because the claimant did not prove that if she had been duly notified of the terms of insurance, she would have concluded an insurance contract with a wider scope of protection, which would imply a need to pay higher insurance premium, Cass. com., 31 mai 2011, n 10-20043.

21 J. Bigot, La responsabilité..., 33. 


\section{LAW APPLICABLE TO THE ASSESSMENT OF LIABILITY FOR VIOLATION OF DISCLOSURE OBLIGATIONS BY THE INSURER}

The free movement of insurance services and their dematerialized nature are conducive to the conclusion of insurance contracts in circumstances where specific elements of a life situation are relatively dispersed and it is impossible to speak of their concentration within one legal area ${ }^{22}$. As the cross-border insurance market expands ${ }^{23}$, one should also expect a growth in the number of disputes arising from the undue performance of precontractual obligations resulting in the failure to obtain the desired insurance protection. Because of the aforementioned dissimilarities between particular legal systems, it is a question of considerable practical importance to search for the law applicable to the assessment of liability for a loss of chance to become insured attributable to a violation of disclosure obligations.

The discussed issue almost intuitively calls to mind liability for culpa in contrahendo. This concept is not understood uniformly in individual legal systems ${ }^{24}$. The catalogue of actions amounting to instances of culpa in contrahendo includes, however, the omission to provide information which is essential for the decision about concluding the contract or provision of untrue information, and actions resulting in the reduction in the value of the subject of future contractual performance ${ }^{25}$.

The EU legislator devoted to the discussed issue a separate conflict of laws rules under Regulation 864/2007 on the law applicable to non-con-

22 See E. Kowalewski, Problematyka kolizyjnego prawa ubezpieczeniowego, PiP 2005, vol. 2, 21, 23-24; F. Seatzu, Insurance in Private International Law. A European Perspective, Oxford-Portland 2003, 43.

23 The term "cross border insurance," as proposed by E. Kowalewski, has become widespread in Polish legal literature and is used to denote insurance contracts which show a connection with more than one legal area. See E. Kowalewski, Prawo ubezpieczeń gospodarczych. Ewolucja i kierunki przemian, Bydgoszcz 1992, 113-119.

24 V. Monsalve-Caballero, The Legal and Historical Panorama of Culpa in Contrahendo at Contractual Negotiations. An Approach from European and Latin American Law, Revista de Derecho 2013, no. 39, 132-145.

25 M.A. Zachariasiewicz, In: System Prawa Handlowego. Międzynarodowe Prawo Handlowe, vol. 9, ed. W. Popiołek, Warszawa 2013. 
tractual obligations (hereinafter Rome II) ${ }^{26}$. Under Art. 12 of the Rome II Regulation, the law applicable to a non-contractual obligation arising out of dealings prior to the conclusion of a contract, regardless of whether the contract was actually concluded or not, is, in principle, the law that applies to the contract or that would have been applicable to it had it been entered into [law applicable to the contract designated under the norms of the Regulation 593/2008 on the law applicable to contractual obligations $^{27}$ (Rome I)]. Only where on that basis the relevant law cannot be found, one should apply conflict of laws rules based on connectors characteristic of tortious obligations (Art. 12(2)).

According to the conception of autonomous interpretation, the term culpa in contrahendo should be read in isolation from the meaning attached to it in the laws of individual Member States ${ }^{28}$. Interpretative guidance in this regard is provided by the wording of Recital 30 of the Rome II Regulation. Although in the Polish language version of the Regulation it is indicated that the concept of culpa in contrahendo should cover "violations of the secrecy obligation", the English (duty of disclosure), German (die Verletzung der Offenlegungspflicht) and French (la violation du devoir d'informer) language versions of the Regulation point to a positively rendered obligation to provide information.

Only seemingly did the legislator put an end to the disputes about the tortious or contractual qualification of the liability for damage inflicted in consequence of violating pre-contractual obligations. The scope of application of the Rome I Regulation does not cover obligations arising out of dealings prior to the conclusion of a contract (Art. 1(2) letter i ${ }^{29}$, however, the provision of Art. 12 of the Rome II Regulation covers only such "non-contractual obligations" arising out of dealings prior to the conclusion of a contract, which, anyhow, follows from the generally specified scope

26 Regulation (EC) No. 864/2007 of the European Parliament and of the Council of 11 July 2007 on the law applicable to non-contractual obligations (Rome II) (OJ EU L 199 of $31.07 .2007,40)$.

27 Regulation (EC) No 593/2008 of the European Parliament and of the Council of 17 June 2008 on the law applicable to contractual obligations (Rome I) (OJ EU L 177 of 04.07.2008, 6, as amended).

28 See Recital 30 of the Rome II Regulation.

29 See also Recital 10 of the Rome I Regulation. 
of application of the Regulation as an instrument on the law applicable to non-contractual obligations (Art. 1(1)). By juxtaposing the normative contents of those provisions, certain authors argue that the liability for violating pre-contractual obligations is either non-contractual of contractual ${ }^{30}$.

Confirmation of such distinction on the conflict of laws level is sought in the well-established judicial opinion, developed for the purpose of applying rules of jurisdiction ${ }^{31}$. In the ECJ judgment in the Tacconi case, it was emphasized that the jurisdiction to examine disputes relating to the liability for damage caused at a stage prior to the conclusion of a contract should be established under the norms covering claims arising out of non-contractual obligations when the damage does not follow from violation of a freely incurred obligation ${ }^{32}$. In the same way, the Court, at least indirectly, expressed the view that liability for damage prior to the conclusion of a contract does not constitute a uniform category ${ }^{33}$.

In light of the rules outlined above, the insurer's liability for violation of disclosure ${ }^{34}$ and advisory duties ${ }^{35}$ imposed on the insurer at the stage

30 N. Hage-Chahine, Culpa in Contrahendo in European Private International Law, Northwestern Journal of International Law \& Business 2012, vol. 32, 466 et seq.; I. Kull, M. Torga, Fitting the Estonian Notions of Contractual and Non-contractual Obligations under the European Private International Law Instruments, Juridica International 2013, vol. 20, 67.

31 N. Hage-Chahine, Culpa..., p. 466 et seq.; I. Kull, M. Torga, Fitting..., 67.

32 Judgment of the ECJ of 17 September 2002 in the case C-334/00 Fonderie Officine Meccaniche Tacconi SpA v. Heinrich Wagner Sinto Maschinenfabrik GmbH, ECR 2002, p. I-7357, items 22-23.

33 The contractual qualification of the relationship is decided by whether a violation refers to an obligation freely incurred by one party vis-a-vis another at the stage preceding the conclusion of a contract. This category includes an obligation under the agreement organizing the negotiation procedure and other pre-contractual arrangements as well as obligations under a promise made prior to the conclusion of a contract. P. Grzegorczyk, Jurysdykcja krajowa w sprawach z zakresu prawa własności przemysłowej, Warszawa 2007, 559-560.

34 See Ł. Żarnowiec, Prawo właściwe dla odpowiedzialności z tytułu culpa in contrahendo na podstawie przepisów rozporządzenia Parlamentu Europejskiej i Rady (WE) - Rzym II, Europejski Przegląd Sądowy 2010, vol. 2, p. 24 and the German literature cited therein; R. Jafferali, Rome II ou la loi applicable aux obligations non contractuelles, Revue générale des assurances et de la responsabilité 2008, p. 14399(6).

35 See H. Heiss, Insurance Contracts in Rome I: Another Recent Failure of the European Legislature, Yearbook for Private International Law 2008, vol. 10, 264; A. Staudinger, In: Rome I Regulation. Pocket Commentary, ed. F. Ferrari, Munich 2015, 286. 
preceding the conclusion of an insurance contract is assessed in accordance with the law found under the norm of Art. 12 of the Rome II Regulation ${ }^{36}$. At the stage of violating disclosure obligations, there is still no freely incurred obligation between the parties ${ }^{37}$.

Commentators generally agree that the law applicable to culpae in contrahendo as found under Art. 12 of the Rome II Regulation decides about the compensatory liability for violations of pre-contractual disclosure obligation $s^{38}$, including the basis and scope of liability (Art. 15 letter a of the Rome II Regulation), and about the existence, nature, and assessment of damage or the remedy claimed (letter c).

While delimiting the scope of the law applicable to culpa in contrahen$d o$, one should, however, answer the question of whether the law designated under Art. 12 of the Rome II Regulation is relevant to the assessment of the scope and content of disclosure obligations.

Certain authors answer that question in the affirmative ${ }^{39}$, whereas others indicate that it is the law directly designated by the norms of the Rome I Regulation that decides about the content of disclosure obligations at the pre-contractual stage ${ }^{40}$.

This question is of limited practical significance in the context of violating insurance disclosure obligations. The law applicable to culpae

36 Ibid, p. 284.

37 Ł. Żarnowiec, In: System Prawa Prywatnego. Prawo Prywatne Międzynarodowe, ed. M. Pazdan, vol. 20B, 853.

38 A. Bauknecht, Culpa in contrahendo wobec unifikacji prawa prywatnego w Europie, Berlin 2014, 190; M.A. Zachariasiewicz, Kwalifikacja „culpa in contrahendo” w prawie prywatnym międzynarodowym, Problemy Prawa Prywatnego Międzynarodowego 2008, vol. 3, 37-53.

39 This comment refers also to such information which will allow the counterparty to prevent the conclusion of an agreement under circumstances in which it would be invalid, I. Bach, In: Rome II Regulation: Pocket Commentary, ed. P. Huber, Munich 2011, 314; see, in reference to precontractual obligations in Belgian law, P. Demolin, L'information précontractuelle et la Commission d'arbitrage. Commentaires de la loi du 2 avril 2014 portant insertion du Titre 2 du Livre X du Code de droit économique, Bruxelles 2014, 125; see also, in the context of contracts of sale with a cross-border element, G. Dannemann, In: The Common European Sales Law in Context: Interactions with English and German Law, eds. G. Dannemann, S. Vogenauer, Oxford 2013, 37.

${ }^{40}$ M.A. Zachariasiewicz, Kwalifikacja..., 58. 
in contrahendo generally corresponds to the law applicable to the insurance contract ${ }^{41}$.

These two can be discordant, on an exceptional basis, when the parties make a partial choice of law for an insurance contract or a choice of law applicable to culpa in contrahendo under Art. 14 of the Rome II Regulation, which at the stage preceding occurrence of the event giving rise to a damage (sc. violation of disclosure obligations) is possible only in relations between entrepreneurs and under a freely negotiated agreement ${ }^{42}$.

As opposed to the unlimited choice of law under Art. 14 of the Rome II Regulation, the choice of law applicable to an insurance contract, apart from insurance contracts covering so-called large risks, is limited in nature $^{43}$. If the scope and content of disclosure obligations is specified by the relevant law found under the Rome II Regulation, a situation is possible when the resolution in respect of such obligations must be made under a law that could not have been chosen by the parties for the insurance contract. It may be considered if the adoption of such solution is legitimate since, seemingly, it implies violation to the integrity of the law applicable to the insurance contract, which - because of the tendency to protect the weaker party of the insurance contract - is generally designated by inflexible connectors of an objective nature.

It seems that this doubt may be removed by a qualification demarcating the spheres of application of the conflict of laws rules under Art. 7 of the Rome I Regulation and Art. 12 of the Rome II Regulation. The former provision refers to the performance of obligations arising from a contract ${ }^{44}$, the latter one - to the terms on which the parties reach the stage when such obligations are incurred. However, one may defend the position that the law applicable to contractual obligations covers the process of reaching

41 See Art. 12(1) and (2) of the Rome II Regulation.

42 Under the Rome II Regulation, choice of law is admissible after the event giving rise to the damage (Art. 14(1) letter a). Choice of law prior to the occurrence of an event giving rise to the damage is admissible only "where all the parties are pursuing a commercial activity" (Art. 14(1) letter b).

43 Art. 7(3) of the Rome I Regulation. More in M. Fras, In: System..., 589.

44 See Art. 12(1) letter b and letter c of the Rome I Regulation, which refer to performance of contractual obligations. 
consensus from the very beginning ${ }^{45}$, that is also at the time of mutual explanation of the shape of the planned contract by its parties.

The first position is supported by the urge to preserve uniformity of the applicable law within the regime of compensation for culpae in contrahendo. There is a functional connection between the triggering event and its consequences. Evaluation of the cause (sc. what the content of the disclosure obligations was and whether they have been violated) in isolation from its consequences, using norms deriving from different legal orders, involves many complications ${ }^{46}$.

As has been mentioned above, violation of disclosure obligations may lead to the policyholder being granted the rights to influence the content of the contract by way of adjusting such content to the policyholder's expectations or termination of the contract or may allow questioning the contract's existence or validity.

Focusing, in the first place, on the last group of situations, one must point out that the law applicable to contractual obligations covers the existence and validity of the contract ${ }^{47}$, including the right to avoid the consequences of a declaration of intent made in error when the error was caused by violation of the disclosure obligations at the pre-contractual stage ${ }^{48}$. The preconditions to the validity of a legal act, especially ones relating to vices of consent, should be assessed under the provisions of the law

45 M.A. Zachariasiewicz, Kwalifikacja..., 58.

46 In the context of partial choice of law under the Rome II Regulation, cf. R. Vander Elst, L'autonomie de la volonté en droit international privé français et belge, In: Liber Amicorum Baron Louis Fredericq, vol. II, Gent 1996, p. 991. It must be noted that solutions from outside the law applicable to culpa in contrahendo may apply under Art. 17, under which "[in] assessing the conduct of the person claimed to be liable, account shall be taken, as a matter of fact and in so far as is appropriate, of the rules of safety and conduct which were in force at the place and time of the event giving rise to the liability."

${ }^{47}$ More on the scope of the law applicable to contractual obligations in respect of insurance contracts in M. Fras, K. Pacuła, Umowa ubezpieczenia obowiązkowego w prawie prywatnym międzynarodowym, In: E. Kowalewski, W. Mogilski eds., System prawny ubezpieczeń obowiązkowych. Przesłanki i kierunki reform, Toruń 2014, 178.

48 R.A. Garcia, La regulación de la responsabilidad precontractual en el Reglamento Roma II, InDret. Revista para el Análisis del Derecho 2008, no. 4, 13; P. Rogerson, J. Collier, Collier's Conflict of Laws, Cambridge 2013, 346. 
applicable to the contract ${ }^{49}$. This solution, according to a well-established tradition of private international law, was also adopted within the framework of the Rome I Regulation ${ }^{50}$. Besides, it would be difficult to neglect the position taken in this regard by the law applicable to contractual obligations, which provides for specific consequences of vices in the process of reaching consensus by the parties ${ }^{51}$. From the perspective of lex causae, the fact that they are consequences of untrue information or omission to provide information is of secondary importance in relation to the principal question about the future of the planned contract ${ }^{52}$. It must be pointed out that this may give rise to a situation in which the contract is found invalid pursuant to the provisions of the law applicable to contractual obligations and, at the same time, the policyholder obtains compensation under the law applicable to culpae in contrahendo $0^{53}$.

As regards other consequences of violating pre-contractual disclosure obligations, certain authors are prone to narrow down the scope of the norm under Art. 12 of the Rome II Regulation only to compensatory liability. It is indicated, for example, that a party's right to terminate the contract for violation of disclosure obligations should be evaluated according to the law applicable to contractual obligations ${ }^{54}$.

49 M. Pazdan, Prawo prywatne międzynarodowe, Warszawa 2012, 127.

50 Art. 10(1) of the Rome I Regulation provides that the existence and validity of a contract, or of any term of a contract, shall be determined by the law which would govern it under this Regulation if the contract or term were valid. Moreover, the question of the return of what had been performed between the parties to a contract which was eliminated from the legal practice is also subject to the law applicable to contractual obligations. Under Art. 12(1) letter e of the Rome I Regulation, the law applicable to the contract is relevant, in particular, to the consequences of the contract's invalidity.

51 In this spirit, M.A. Zachariasiewicz, In: Tort Law in Poland, Germany and Europe, eds. B. Heiderhoff, G. Żmij, Munich 2009, 149.

52 These circumstances, however, will be taken into consideration as reasons for a contract's (relative or absolute) invalidity.

53 It does not seem that in this case one may expect the intervention of mandatory overriding provisions or the public policy clause since certain legal systems allow to challenge the contract's legal existence and simultaneous pursuit of compensatory claims.

54 In justification of that position, the scope of the law applicable to contractual obligations is invoked, as specified in Art. 12(1) of the Rome I Regulation, which relates to the consequences of full or partial non-performance of an obligation (letter c) and different types of extinction of obligations (letter d); I. Bach, In: Rome II..., 314. 
While generally agreeing with that position, one should note that in the Rome II Regulation the concept of loss covers "all consequences arising out of culpa in contrahendo" (Art. 2(1)) and the applicable law found on its basis decides about the existence, nature, and assessment of damage or the remedy claimed in relation to such damage (Art. 15 letter $\mathrm{c})^{55}$. If the remedy concerning the so understood damage is the right exercised in relation to the subsequently concluded contract, one should apply in this regard provisions of the law relevant to events referred to as culpa in contrahendo. If that law sets out, for example, that a consequence of the disclosure obligations being violated by the insurer at the pre-contractual stage is the right to claim the contract's adjustment ${ }^{56}$, and this is not afforded by the law applicable to contractual obligations, it would not be desirable to deprive the policyholder on that basis of the protection deriving from the law applicable to culpae in contrahendo. Disharmony between norms belonging to different legal systems may be removed by way of adjustment (l'adaptation) ${ }^{57}$.

\section{LAW APPLICABLE TO THE ASSESSMENT \\ OF LIABILITY FOR VIOLATION OF DISCLOSURE OBLIGATIONS BY THIRD PARTIES VIS-A-VIS THE INSURER}

It must be noted that in a significant number of cases, insurance contracts are concluded through a third party: broker, agent or organizer in group insurance contracts.

55 In this spirit, B. Schinkels, In: Rome Regulations. Commentary on the European Rules of the Conflict of Laws, ed. G.P. Calliess, Alphen aan den Rijn 2011, 524.

56 Citing opinions found in German literature, P. Tereszkiewicz indicates that situations of violating the advisory obligation may authorize the policyholder to terminate the contract for an important reason. See P. Tereszkiewicz, Obowiązki..., 324.

57 Adjustment may, among others, "consist in the creation of a sui generis synthesis of the norms found in different legal systems as though they originated from one legislator," and when this proves impossible, "such norms must be replaced by substantial a norm of private international law formulated by the judge for the purpose of a specific case". M. Pazdan, Prawo..., 85. 
An insurance broker is tied by a legal relationship to a person seeking insurance protection with the broker's involvement or through the broker. The provision of adequate information is, besides the duty of competence, the most important obligation imposed on every professional, including insurance brokers ${ }^{58}$. As a result, brokers are obliged to precisely analyze the insurance risk relating to the customer (so-called risk assessment) and have the functionally related advisory duty regarding the adequacy of the insurance protection. The disclosure and advisory duty of an insurance broker are aimed at recommending to the customer the possibly most favorable insurance contract, considering the current status of that customer's insurance protection and his actual needs. Apart from situations in which the principal seeks the source of the broker's liability in a tort, it is the applicable law found under the Rome I Regulation to resolve in respect of the scope and content of the disclosure obligation as well as liability for its violation.

On the other hand, there is no contract between an insurance agent and a person applying for insurance protection. An agent acts on behalf of the insurer to whom, as a rule, he is tied by an agency relationship.

When delimiting the scope of application of the norm under Art. 12 of the Rome II Regulation, one should resolve whether that norm covers the liability of third parties for acts and omissions at the stage preceding the conclusion of a contract by the parties. In the doctrine of private international law, no uniform position has, thus far, been established ${ }^{59}$.

Certain authors are of the opinion that liability for culpa in contrahendo may be incurred only by the parties to the contract to whose conclusion the acts made at the pre-contractual stage directly lead ${ }^{60}$. On the other hand, the liability of third parties is decided by the law found under

58 See M. Fras, Odpowiedzialność..., 3 et seq.

59 B. Schinkels, In: Rome..., 527-529. Differences in this regard are also observable in substantive law. In Polish law, the conception of culpa in contrahendo covers also faulty conduct of third parties as long as they are connected with the contractual parties. M.A. Zachariasiewicz, In: Tort Law..., 147. Similar opinion in the context of German law is discussed in B.S. Markesinis, H. Unberath, A. Johnston, The German Law of Contract: A Comparative Treatise, Oxford 2006, 93.

60 P. Rogerson, J. Collier, Collier's..., 346. 
Art. 4 of the Rome II Regulation ${ }^{61}$. In the doctrine, one may also find an opposite opinion, according to which the scope of the norm under Art. 12 of the Rome II Regulation covers as well the question of liability of persons engaged in the contracting process ${ }^{62}$.

While adopting the latter position, one should emphasize that the norm under Art. 12 refers to obligations "directly relating" to dealings prior to the conclusion of a contract ${ }^{63}$. This relation should be understood as a functional connection between the pre-contractual obligations and the contract to the conclusion of which the parties are heading ${ }^{64}$. This feature may refer to acts of third parties who are directly involved in the process of reaching consensus between the parties. The proposed solution promotes also legal certainty. An active participant of the negotiation procedure is capable of anticipating what law is going to be designated as applicable to the contract to be concluded by the parties ${ }^{65}$. In this way, also the interests of the injured party are protected. The same applicable law is relevant to the assessment of liability of the counterparty to the negotiation procedure and its representatives ${ }^{66}$.

Moreover, delimitation of the scope of Art. 12 of the Rome II Regulation by the criterion of functional relation between pre-contractual obligations and the planned contract means that the law found under that norm is relevant to the assessment of interests of the insured party who has not obtained insurance protection due to violation of a disclosure obligation in the relation between the insurer and the policyholder ${ }^{67}$.

${ }^{61}$ A. Dickinson, The Rome II Regulation: The Law Applicable to Non-Contractual Obligations, Oxford 2008, 528; A. Dutta, Das Statut der Haftung aus Vertrag mit Schutzwirkung für Dritte, Praxis des Internationalen Privat- und Verfahrensrechts 2009, vol. 4, 293 et seq.

62 I. Bach (win:) Rome II..., 216.

63 See Recital 30 of the Rome II Regulation.

64 B. Volders, Culpa in Contrahendo in the Rome II Regulation, Yearbook of Private International Law 2007, vol. 9, 131.

65 I. Bach (in:) Rome II..., 217.

66 It must be noted that the law found under the norms of the Rome II Regulation resolves whether the insurer is jointly and severally liable for an agent's acts or omissions (Art. 15 letter g).

${ }_{67}$ B. Schinkels, In: Rome..., 528. 
A peculiarity of group insurance contracts, deriving from the specific position of the group organizer as a person seeking to ensure insurance protection to the group members (insured parties), is that the organizer is imposed, to a narrower or wider ${ }^{68}$ extent, with disclosure obligations. A consequence of their violation may be a loss of chance to become insured on the part of a group member.

Search for a conflict of laws rule relevant to the evaluation of a question arising against the backdrop of the relation between a group member and its organizer should be preceded by a number of comments on the very construction of group insurance.

As a rule, group members are tied to the organizer by an extra-insurance internal relationship which justifies the conclusion of the group insurance contract. Its establishment predates the formation of the insurance relationship. Therefore, the opinion of the Supreme Court has not become outdated according to which the disclosure obligation in group insurance may follow from an extra-insurance relationship between the group organizer and a person seeking insurance protection or from the provisions of a contract for the group insurance concluded between the organizer and the insurer ${ }^{69}$.

Disclosure obligations under the internal relations are an example of a freely incurred obligation towards a group member, which predetermines their contractual nature. This internal relationship is characterized by the conflict of law's independence. At the same time, it is an extra-insurance relationship. In consequence, it is not covered by the scope of Art. 7 of the Rome I Regulation.

There are more doubts relating to pre-contractual disclosure obligations whose source is outside the internal relationship.

It is indicated in the literature that the conclusion of a group insurance contract results in the establishment - through the policyholder of a legal relationship between the insurer and the insured party. In the

68 Under Art. L 141-4 of the Insurance Code, the group organizer delivers to the insured party a document prepared by the insurer which contains, among others, information on the scope of protection under the insurance contract. The scope of that duty is strongly shaped by case-law, with a clear tendency for its extension. D. Krajeski, In: Droit..., 1429.

69 Resolution of the Court Supreme of 8 November 1977, I PZP 48/77, Legalis No. 20483. 
author's opinion, this observation is universal although "[in] certain legal systems [group insurance] is treated as a multitude of individual insurance relationships between the same policyholder and the insurance company. Others classify the group insurance contract as a framework agreement between the policyholder and the insurance company, relating to individual insurance relationships emerging between the insurance company and the insured parties. ${ }^{\prime 0}$

In the context of French law, a distinction is made, already within the framework of one substantive law regime, between group insurance with compulsory accession (assurance de groupe à l'adhésion obligatoire), in which the insurance protection is established automatically upon obtaining the status of a group member and follows from a contract concluded between the group organizer (policyholder) and the insurer, and group insurance with elective accession (assurance de groupe à l'adhésion facultative), which forms a peculiar legal construction, a combination of individual insurance with a special type of framework agreement between the insurer and the group organizer. The framework agreement is not an insurance contract. On the other hand, an individual insurance contract holds between each of the group members (insured parties) and the insurer ${ }^{71}$. It is generally concluded, with the effect of the establishment of insurance protection, as a result of a declaration of accession being made.

Similarly, in German literature, authors distinguish between the socalled proper group insurance contract (echte Gruppenversicherung), in which the group organizer is at the same time the policyholder, and the so-called improper group insurance contract (unechte Gruppenversicherung), which is based on the abovementioned construction of a framework agreement between the organizer and the insurer ${ }^{72}$.

70 M. Kropka, Prawo właściwe dla umowy ubezpieczenia następstw nieszczęśliwych wypadków. Glosa do wyroku Sądu Najwyższego z dnia 3 lutego 2006 r., II PK 152/05, Problemy Prawa Prywatnego Międzynarodowego 2007, vol. 2, 201-202 and the literature cited therein.

71 J. Bigot, In: Traité de Droit des assurances. Tome 3. Le contrat d'assurance, ed. J. Bigot, Paris 2002, 132 et seq.; L. Mayaux , In: Traité de Droit des assurances. Tome 4. Les assurances de personnes, ed. J. Bigot, Paris 2007, 666 et seq.

72 More in F. Herdter, Der Gruppenversicherungsvertrag - Grundlagen und ausgewählte Problemfelder, Karlsruhe 2010, 14 et seq.; This terminology was coined by 
This solution was also adopted by the authors of the model instrument governing insurance contracts, the Principles of European Insurance Contract Law (PEICL) ${ }^{73}$, which is developed with the use of results of comparative law research. Researchers from the Restatement Group decided to introduce a distinction between group insurance with compulsory (accessory group insurance) and elective (elective group insurance) accession ${ }^{74}$.

It would be difficult to speak of a violation of disclosure obligations with the effect of a lost chance to become insured in case of group insurance with compulsory accession. In this case, protection emerges automatically. It is a consequence of adherence to the group. If the group organizer (policyholder) concludes for the benefit of the group's member (insured party) a group insurance contract which does not ensure to the member the desired level of protection, the assessment of liability for such a situation should be referred to the internal relationship. It is the internal relationship that may give rise to the obligation to ensure specific protection in the form of insurance to the group member.

How to find the law applicable to the assessment of liability of a group organizer for violation of disclosure obligations in a group insurance contract with elective accession if such obligations arise from the agreement between the organizer and the insurer?

A group member is not a party to that agreement. This seems to decide about the non-contractual character of the organizer's liability for damage caused to a group member at the stage prior to his accession to the insurance $^{75}$. In the doctrine of private international law, it is nevertheless

H. Millauer, Rechtsgrundsätze der Gruppenversicherung, Karlsruhe 1954, 107 et seq.

73 M. Lakhan, H. Heiss, An Optional Instrument for European Insurance Contract Law, Utrecht Journal of International and European Law 2010, vol. 26, 1-11.

74 D. Fuchs, Ubezpieczenia grupowe w europejskiej umowie ubezpieczenia, O potrzebie uregulowania ubezpieczeń grupowych, conference materials, Warsaw 15 November 2013 r.; A. Daszewski, A. Dą̧browska, O potrzebie zmiany przepisów kodeksu cywilnego o umowie ubezpieczenia $\mathrm{w}$ kontekście uregulowania ubezpieczeń grupowych, In: M. Serwach ed., Rynek ubezpieczeniowy - nadregulacja czy niedoregulowanie, Łódź 2014, 187.

75 The situation of a group member in relation to the group's organizer is quite different from the situation of an insured party in relation to the insurer obliged to provide him with insurance protection. The law applicable to the insurance contract is relevant to the assessment of rights of a third party for whose benefit specific performance was stipulated 
assumed that the question of personal liability of an agent for the damage caused as a consequence of the undue performance of disclosure obligations is decided by the law found under Art. 12 of the Rome II Regula$\operatorname{tion}^{76}$. This observation refers to all situations in which a party decides to enter into the contract acting in reliance on the information provided by a third party ${ }^{77}$, even if such third party is tied to the counterparty by a contractual relationship.

\section{JURISDICTION IN MATTERS RELATING TO THE LOSS OF CHANCE} TO BECOME INSURED

Under the Regulation (EU) No 1215/2012 of the European Parliament and of the Council of 12 December 2012 on jurisdiction and the recognition and enforcement of judgments in civil and commercial matters $^{78}$ (hereinafter Brussels I bis Regulation), jurisdiction in matters relating to insurance is asymmetrical. The rules of jurisdiction are different depending on whether the "weaker party" of an insurance relationship takes the role of claimant or defendant. The policyholder, insured party, beneficiary or injured party having a claim under the insurance relationship is

by the parties. See A. Bělohlávek, Rozporządzenie Rzym I. Konwencja rzymska. Komentarz, vol. 2, Warszawa 2010, 185. However, one should not equate this formula with a construction of a contract with a protective consequence for a third party (Vertrag mit Schutzwirkung für Dritte), by which certain German authors explain the scope of obligations of the group organizer towards the group's members. It assumes that a debtor is obliged to exercise, while performing, special care not only vis-a-vis the creditor but also certain third parties (e.g. in the context of disclosure obligations). B. Hesse, Interessenkonflikte bei der Lebensversicherung zugunsten Dritter, Karlsruhe 1981, 150. This obligation, however, is accessory to the main performance stipulated for the creditor's benefit. A third party may not demand such performance for the third party's benefit, which is why this construction is denied contractual nature by P. Mankowski, In: Brussels I Regulation, eds. U. Magnus, P. Mankowski, München 2007, 121.

76 I. Bach (in:) Rome II..., 217.

77 B. Schinkels, In: Rome..., 528.

78 Regulation (EU) No 1215/2012 of the European Parliament and of the Council of 12 December 2012 on jurisdiction and the recognition and enforcement of judgments in civil and commercial matters (OJ EU L 351 of 20.12.2012, 1, as amended). 
allowed to sue the insurer before a forum expedient to such weaker party, determined according to the residence of the claimant, whereas the insurer may generally sue exclusively before the courts of the country of residence of the defendant.

Special rules of jurisdiction apply to "matters relating to insurance" (Art. 10). Therefore, it seems that by delimiting the scope of their application, one should limit oneself to matters pertaining to contractual claims. However, in light of the provision of Art. 12 of the Rome II Regulation and its Recital 30, it is unlikely that such qualification of claims for the violation of pre-contractual disclosure obligations is going to be adopted in case-law.

Whereas the ECJ, in the Tacconi case, drew attention to the fact that pre-contractual obligations may assume a contractual or non-contractual form, after the entry into force of the Rome II Regulation, the lawmaker clearly leans towards the non-contractual qualification of claims for violation of pre-contractual disclosure obligations. Bearing in mind the postulate of coherence between the Rome Regulations and the Regulation on jurisdiction, the introduction of a special conflict of laws rule for non-contractual obligations arising out of dealings will not be without significance for the application of jurisdiction rules ${ }^{79}$. Such direction in the delimitation of the scope of jurisdiction norms, consistent with the non-contractual qualification of culpa in contrahendo under the Rome II Regulation, was anticipated in the literature even prior to its entry into force ${ }^{80}$.

Disputes for the payment of compensation for a lost chance to become insured will probably be considered by the courts of the Member

79 This does not mean, however, that it is the only acceptable way of thinking. It may be also accepted that claims for violation of precontractual disclosure obligations are of contractual nature in the jurisdictional context, which is not consistent with their qualification in the conflict of laws context. This point of view is amply discussed in N. Hage-Chahine, Culpa..., 468-470.

80 P. Mankowski, In: Brussels..., 117; See also J. Gołaczyński, Jurysdykcja, uznawanie orzeczeń sądowych oraz ich wykonywanie w sprawach cywilnych i handlowych. Rozporządzenie Parlamentu Europejskiego i Rady (UE) nr 1215/2012. Komentarz, Warszawa 2015, 34 et seq, where the author suggests that the non-contractual qualification of claims relating to a strike, as dictated by the scope of the norm under Art. 9 of the Rome II Regulation, predetermines also their qualification in the area of jurisdiction. 
State in which the sued insurer is domiciled (Art. 4(1) of the Brussels I bis Regulation) or the courts of the place where the harmful event occurred (Art. 7 item 2). The same terms will apply in case of claims asserted against an agent.

If, however, the damage was caused by an act of an agent for whom the insurer is responsible, a suit against the insurance company may also be brought before the court of the place where the agency is situated (Art. 7 item 5). The provision of Art. 7 item 5 allows to base jurisdiction on the place where the agent is situated in matters involving disputes arising out of such agent's activities. The scope of that norm includes as well non-contractual disputes ${ }^{81}$.

One may speak of existence of a "branch, agency or establishment" of the main entrepreneur if a given entity has a management structure and property structure of such type that a third party may negotiate contracts with such entity without a need of direct involvement of that entrepreneur although, eventually, the legal relationship will be established between such entrepreneur and the third party ${ }^{82}$. The absence of control over the activities of a given entity and absence of the duty to follow the main entrepreneur's orders preclude the conclusion that a given entity is a branch, agency or establishment ${ }^{83}$. Analysis of the ties between a branch and the main entrepreneur may not be limited exclusively to the examination of formal organizational and legal ties. Even in the absence of such ties, the admissibility to recognize a given entity as a branch is decided by the objective relations between such entities from the perspective of third parties ${ }^{84}$.

Most legal literature in which an attempt is made to transpose those patterns to insurance relationships concentrates on the juxtaposition of an insurance broker and an insurance agent, and uses the term "branch,

${ }^{81}$ Judgment of the ECJ of 22 November 1978 in the case 33/78 Somafer SA v. Saar-Fergnas AG, ECR 1978, 2183, item 13.

82 Ibid, item 12.

83 Judgment of the ECJ of 6 October 1976 in the case 14/76 A. De Bloos, SPRL v. Société en commandite par actions Bouyer, ECR 1977, p. 149, item 20-21.

${ }^{84}$ Judgment of the ECJ of 9 December 1987 in the case 218/86 SAR Schotte GmbH v. Parfums Rothschild SARL, ECR 1987, p. 4905, item 14-17. 
establishment or agency" only in reference to the latter ${ }^{85}$. This distinction is based on the conviction that a broker has an autonomous position visa-vis the insurer, whereas an agent acts in correlation with the insurer ${ }^{86}$. In consequence, an entity that pursues its activities independently and is not obliged to follow the instructions it is given may not be considered to be a branch of the agency ${ }^{87}$.

A broker infringing a disclosure obligation unduly performs the contract with the principal. Such principal may bring a claim for a loss of chance of insuring before the courts of the country of the broker's domicile (Art. 4 item 1 of the Brussels I bis Regulation) or before the court of the country in which, under the contract, brokerage services were provided or should have been provided (Art. 7 item 1 letter b). However, the connector under Art. 7 item 1 letter b of the Regulation may sometimes be a source of trouble. The place of provision of the service should be established, in the first place, according to the intention of the parties as expressed in the content of the contract. Only secondarily, "where the provisions of the contract do not permit determination of the place of the main rendition of services," one should alternatively consider the place where the service provider acted if such determination is not contrary to "the parties' intention as expressed in the provisions of the agreement." ${ }^{88}$ Following that rule, the Polish Supreme Court expressed an opinion that the place of provision of legal consultancy services is the seat of the service provider, where draft agreements and opinions are drawn up, and not the place where such documents are used by their recipients ${ }^{89}$. Applying these remarks to the le-

85 See K.F. Tsang, Forum Shopping in European Insurance Litigation: What We Have Learned from New Hampshire Insurance Co. v. Strabag Bau, Loyola of Los Angeles International and Comparative Law Review 2010, vol. 32, 246, footnote 39.

${ }^{86}$ H. Heiss, In: Brussels I Regulation, eds. U. Magnus, P. Mankowski, München 2007, 281-282.

87 See, in the context of the Lugano Convention, R. Stefanicki, Jurysdykcja w sprawach ubezpieczeniowych według Konwencji Lugańskiej, WU 1999, vol. 9-10, 38.

${ }_{88}$ Judgment of the ECJ of 11 March 2010 in the case C-19/09 Wood Floor Solutions Andreas Domberger GmbH v. Silva Trade SA, ECR 2010, p. I-02121, items 38, 40 - hereinafter, the ECJ judgment in the Wood Floor case.

89 Decision of the Supreme Court of 22 January 2015, I CSK 668/13, Legalis No. 1200707. 
gal position of a broker, one may assume that - unless the parties agreed otherwise - the place of performance of a service consisting in preparation of an insurance program is the broker's seat, even if the broker carries out, under the concluded contract, a number of additional (auxiliary) activities out of his seat. In case of a multitude of places of providing services in different Member States, the goal should be to indicate one court competent for all claims arising out of the contract. This will be decided by the place of the main performance ${ }^{90}$, which, however, does not have to correspond to the broker's domicile ${ }^{91}$. On a side note, it must be indicated that the injured party may also base the broker's liability on a tort (Art. 7 item 5). However, the court competent on that basis has no jurisdiction to resolve a case for compensation brought on contractual grounds ${ }^{92}$.

As far as the liability of an organizer in group insurance is concerned, the starting point is an analysis of the ties between such an organizer and a group member.

If the disclosure duty follows from an obligation freely incurred as a part of an extra-insurance internal relationship, cases for compensation based on its violation are contractual. For example, in employee group insurance contracts, special norms on employment contracts will apply (Art. 20 and following of the Brussels I bis Regulation).

It seems that is if the disclosure obligation follows from a framework agreement organizing the insurance, jurisdiction should be established under the non-contractual qualification of a claim. A member of the group is not a party to that agreement although it is concluded in such member's interest.

90 ECJ decision in the Wood Floor case, items 27 and 33.

91 Determination of the place of main performance may imply complications when the service provider, in a contract similar to insurance intermediation or legal consultancy, undertakes primarily to act in the name and on behalf of the client vis-a-vis third parties. Cf. K. Pacuła, Forum shopping i kolizyjnoprawne obejście prawa w działalności ubezpieczeniowych kancelarii odszkodowawczych, In: E. Kowalewski ed., Doradztwo odszkodowawcze w Polsce. Potrzeba regulacji prawnej, Toruń 2015, 177 et seq.

92 In this regard, the opinion of M. Pazdan has not become outdated, as expressed in M. Pazdan, Zbieg odpowiedzialności cywilnej ex contractu i ex delicto w prawie prywatnym międzynarodowym, In: J. Błeszyński, J. Rajski eds., Rozprawy z prawa cywilnego. Księga pamiątkowa ku czci Witolda Czachórskiego, Warszawa 1985, 294. 


\section{CONCLUSION}

Despite the specific conflict of laws rule for the liability for culpa in contrahendo in the Rome II Regulation, the law applicable to the assessment of the liability for a loss of chance to become insured is, in principle, the law relevant to the insurance contract itself. Under Art. 12(1) of the Rome II Regulation, the law applicable in this case is basically lex contractus in negotio.

More doubts are raised by the assessment of the same issue on the level of jurisdiction. One may consider if, in the case of disputes concerning the liability for violation of insurance disclosure obligations, the claimant should not take advantage of the special rules of the jurisdiction from Chapter II Section 3 of the Brussels I bis Regulation. This is supported also by the need to protect the policyholders and the insured parties. If one is to apply the comments made in the context of the insurer's pre-contractual obligations to analogous obligations in respect of the declaration of risk, which are imposed on the weaker party of the insurance contract, it will turn out that in a dispute arising from their violation such person, acting as the defendant, will not enjoy the protection under the rules of jurisdiction contained in Chapter II Section 3 of the Regulation.

An inducement in this regard is offered by Art. 10 of the Brussels I bis Regulation, which delimits the scope of application of special jurisdiction rules "in matters relating to insurance." Its wording differs from the two remaining provisions of similar nature, which provide respectively for the application of special jurisdiction rules if the subject of the proceedings is an employment contract or claims under an employment contract (Art. 20(1)) or a contract or claim under a contract concluded by a consumer (Art. 17). In the provisions of Art. 10 and following of the Brussels I bis Regulation, it is not clearly indicated that the claim should arise from "an insurance contract," which may open the way for the coverage by these provisions of disputes with non-contractual qualification ${ }^{93}$.

93 It does not seem that this point of view is precluded by the assumption that the discussed norms are exceptions to a general rule and, as such, may not be interpreted extensively. The argument based on the exceptiones non sunt extendendae principle may not result in rendering invalid those provisions which are protective in nature. See the opinion 
The case-law points as well to the possibility to widen the scope of application of those norms to disputes conducted on the initiative of the injured parties ${ }^{94}$, their legal successors ${ }^{95}$, and disputes conducted against the injured parties themselves ${ }^{96}$ or against persons merely related to the insurance relationship ${ }^{97}$. These persons are not the parties to the insurance contract. However, they take advantage of special protection in the area of jurisdiction on account of the endeavor to implement the postulate of protecting the "weaker party." As a consequence, a conclusion may be drawn that, under the provisions of Chapter II Section 3, the relation between the dispute and the insurance contract should not be understood narrowly if this could stand in opposition with the purpose of special jurisdiction rules.

\section{REFERENCES}

Bach I. In: Rome II Regulation: Pocket Commentary, ed. P. Huber, Munich 2011. Bagińska E., Odpowiedzialność deliktowa w razie niepewności związku przyczynowego. Studium prawnoporównawcze, Warszawa 2013.

Bauknecht A., Culpa in contrahendo wobec unifikacji prawa prywatnego w Europie, Berlin 2014.

Bělohlávek A., Rozporządzenie Rzym I. Konwencja rzymska. Komentarz, vol. 2, Warszawa 2010.

of Advocate General Francis G. Jacobs of 13 December 2001 in the case C-96/00 Rudolf Gabriel v. Schlank \& Schick GmbH, ECLI:EU:C:2001:690, item 47.

94 Judgment of the ECJ of 13 December 2007, C-463/06, in the FBTO Schadeversekeringen N.V. v. Jack Odenbreit case, ECR 2007, p. I-11321.

95 Judgment of the ECJ of 17 September 2009 in the case C-347/08, Vorarlberger Gebietskrankenkasse v. WGV Schwäbische Allgemeine Versicherungs AG, ECR 2009, p. I-08661.

96 The French Court of Cassation concluded that the rules of jurisdiction relating to insurance (currently Art. 14(1) of the Brussels I bis Regulation) apply to actions brought against the injured party, regardless of whether the insurer takes the role of the claimant independently. Cass. civ., 27 février 2013, n 11-23.228.

97 Judgment of the House of Lords in the case Baltic Insurance Group v. Jordan Grand Prix Ltd [1999] 2 AC 127, against whose background such opinion is formulated in P. Stone, EU Private International Law, Cheltenham 2010, 128. 
Bigot J. In: Traité de Droit des assurances. Tome 3. Le contrat d'assurance, ed. J. Bigot, Paris 2002.

Bigot J., La responsabilité civile des sociétés d'assurance à l'égard des assures en droit français (in:) Mélanges Roger O. Dalcq, Bruxelles 1994.

Binon J.M., La réparation de la perte d'une chance dans la jurisprudence européenne: une question de chance? In: Liber Amicorum Jean-Luc Fagnart, Bruxelles 2008.

Dannemann G. In: The Common European Sales Law in Context: Interactions with English and German Law, eds. G. Dannemann, S. Vogenauer, Oxford 2013.

Daszewski A., Dąbrowska A., O potrzebie zmiany przepisów kodeksu cywilnego o umowie ubezpieczenia w kontekście uregulowania ubezpieczeń grupowych, In: M. Serwach, ed., Rynek ubezpieczeniowy - nadregulacja czy niedoregulowanie, Łódź 2014.

Demolin P., L'information précontractuelle et la Commission d'arbitrage. Commentaires de la loi du 2 avril 2014 portant insertion du Titre 2 du Livre X du Code de droit économique, Bruxelles 2014.

Dickinson A., The Rome II Regulation: The Law Applicable to Non-Contractual Obligations, Oxford 2008.

Dutta A., Das Statut der Haftung aus Vertrag mit Schutzwirkung für Dritte, Praxis des Internationalen Privat- und Verfahrensrechts 2009, vol. 4.

Fagnart J.L., La perte d'une chance ou la valeur de l'incertain, In: C. Devoet, J.L. Fagnart, C. Paris, eds., La réparation du dommage. Question particulières, Louvain-la-Neuve 2006.

Fras M., Odpowiedzialność brokera ubezpieczeniowego za niewykonanie lub nienależyte wykonanie zobowiązania: rozważania na tle orzecznictwa Sądu Najwyższego, PA 2009, No. 3.

Fras M. In: System Prawa Handlowego. Międzynarodowe Prawo Handlowe, vol. 9, ed. W. Popiołek, Warszawa 2013.

Fras M., Pacuła K., Umowa ubezpieczenia obowiązkowego w prawie prywatnym międzynarodowym, In: E. Kowalewski, W. Mogilski, eds., System prawny ubezpieczeń obowiązkowych. Przesłanki i kierunki reform, Toruń 2014.

Fuchs D., Ubezpieczenia grupowe w europejskiej umowie ubezpieczenia, O potrzebie uregulowania ubezpieczeń grupowych, conference materials, Warsaw 15 November 2013.

Garcia R.A., La regulación de la responsabilidad precontractual en el Reglamento Roma II, InDret. Revista para el Análisis del Derecho 2008, no. 4.

Gnela B., Umowa konsumencka w polskim prawie cywilnym i prywatnym międzynarodowym, Warszawa 2013. 
Gołaczyński J., Jurysdykcja, uznawanie orzeczeń sądowych oraz ich wykonywanie w sprawach cywilnych i handlowych. Rozporządzenie Parlamentu Europejskiego i Rady (UE) no 1215/2012. Komentarz, Warszawa 2015.

Grzegorczyk P., Jurysdykcja krajowa w sprawach z zakresu prawa własności przemysłowej, Warszawa 2007.

Hage-Chahine N., Culpa in Contrahendo in European Private International Law, Northwestern Journal of International Law \& Business 2012, vol. 32.

Heiss H. In: Brussels I Regulation, eds. U. Magnus, P. Mankowski, München 2007. Heiss H., Insurance Contracts in Rome I: Another Recent Failure of the European Legislature, Yearbook for Private International Law 2008, vol. 10.

Herdter F., Der Gruppenversicherungsvertrag - Grundlagen und ausgewählte Problemfelder, Karlsruhe 2010.

Hesse B., Interessenkonflikte bei der Lebensversicherung zugunsten Dritter, Karlsruhe 1981.

Jafferali R., Rome II ou la loi applicable aux obligations non contractuelles, Revue générale des assurances et de la responsabilité 2008.

Kowalewski E., Prawo ubezpieczeń gospodarczych. Ewolucja i kierunki przemian, Bydgoszcz 1992.

Kowalewski E., Problematyka kolizyjnego prawa ubezpieczeniowego, PiP 2005, vol. 2.

Krajeski D. In: Droit de la responsabilité et des contrats, ed. P. Le Tourneau, Paris 2012.

Kramer A., The Law of Contract Damages, Oxford 2014.

Kropka M., Prawo właściwe dla umowy ubezpieczenia następstw nieszczęśliwych wypadków. Glosa do wyroku Sądu Najwyższego z dnia 3 lutego 2006 r., II PK 152/05, Problemy Prawa Prywatnego Międzynarodowego 2007, vol. 2.

Kucharski B., Naruszenie powinności deklaracji jako podstawa odmowy wypłaty odszkodowania ubezpieczeniowego, Acta Universitatis Lodziensis. Folia Iuridica 2013, No. 72.

Kull I., Torga M., Fitting the Estonian Notions of Contractual and Non-contractual Obligations under the European Private International Law Instruments, Juridica International 2013, vol. 20.

Lakhan M., Heiss H., An Optional Instrument for European Insurance Contract Law, Utrecht Journal of International and European Law 2010, vol. 26.

Mankowski P. (in:) Brussels I Regulation, eds. U. Magnus, P. Mankowski, München 2007.

Markesinis B.S., Unberath H., Johnston A., The German Law of Contract: A Comparative Treatise, Oxford 2006. 
Martens S., Zimmermann R. In: Digest of European Tort Law. Volume 2: Essential Cases on Damage, eds. B. Winiger, H. Koziol, B.A. Koch, R. Zimmermann, Berlin 2011.

Mayaux L. In: Traité de Droit des assurances. Tome 4. Les assurances de personnes, ed. J. Bigot, Paris 2007.

McMeel Cf. G., The FSA's insurance conduct of business regime: a revolution in (consumer) insurance law?, Lloyd's Maritime and Commercial Law Quarterly 2005, No. 2.

Merkin R., Colinvaux's Law of Insurance, London 1997.

Millauer H., Rechtsgrundsätze der Gruppenversicherung, Karlsruhe 1954.

Monsalve-Caballero V., The Legal and Historical Panorama of Culpa in Contrahendo at Contractual Negotiations. An Approach from European and Latin American Law, Revista de Derecho 2013, no. 39.

Nesterowicz M., Utrata szansy wyleczenia lub przeżycia w prawie francuskim, PiP 2010, No. 3.

Pacuła K., Forum shopping i kolizyjnoprawne obejście prawa w działalności ubezpieczeniowych kancelarii odszkodowawczych, In: E. Kowalewski ed., Doradztwo odszkodowawcze w Polsce. Potrzeba regulacji prawnej, Toruń 2015.

Pazdan M., Prawo prywatne międzynarodowe, Warszawa 2012.

Pazdan M., Zbieg odpowiedzialności cywilnej ex contractu i ex delicto w prawie prywatnym międzynarodowym, In: J. Błeszyński, J. Rajski, eds., Rozprawy z prawa cywilnego. Księga pamiątkowa ku czci Witolda Czachórskiego, Warszawa 1985.

Pfeiffer T., New Mechanisms for Concluding Contracts, In: R. Schulze, ed., New Features in Contract Law, München 2007.

Reichert-Facilides F., Contract Law: General Aspects, In: H. Heiss, M. Lakhan, eds., Principles of European Insurance Contract Law: A Model Optional Instrument, München 2011.

Rogerson P., J. Collier, Collier's Conflict of Laws, Cambridge 2013.

Schinkels B. In: Rome Regulations. Commentary on the European Rules of the Conflict of Laws, ed. G.P. Calliess, Alphen aan den Rijn 2011.

Seatzu F., Insurance in Private International Law. A European Perspective, Oxford-Portland 2003.

Staudinger A. (in:) Rome I Regulation. Pocket Commentary, ed. F. Ferrari, Munich 2015.

Stefanicki R., Jurysdykcja w sprawach ubezpieczeniowych według Konwencji Lugańskiej, WU 1999, vol. 9-10.

Stone P., EU Private International Law, Cheltenham 2010. 
Tereszkiewicz P., Obowiązki informacyjne w umowach o usługi finansowe, Warszawa 2015.

Tsang K.F., Forum Shopping in European Insurance Litigation: What We Have Learned from New Hampshire Insurance Co. v. Strabag Bau, Loyola of Los Angeles International and Comparative Law Review 2010, vol. 32.

Vander Elst R., L'autonomie de la volonté en droit international privé français et belge (in:) Liber Amicorum Baron Louis Fredericq, vol. II, Gent 1996.

Volders B., Culpa in Contrahendo in the Rome II Regulation, Yearbook of Private International Law 2007, vol. 9.

Zachariasiewicz M.A. In: System Prawa Handlowego. Międzynarodowe Prawo Handlowe, vol. 9, ed. W. Popiołek, Warszawa 2013.

Zachariasiewicz M.A. In: Tort Law in Poland, Germany and Europe, eds. B. Heiderhoff, G. Żmij, Munich 2009.

Zachariasiewicz M.A., Kwalifikacja „culpa in contrahendo” w prawie prywatnym międzynarodowym, Problemy Prawa Prywatnego Międzynarodowego 2008, vol. 3 .

Żarnowiec Ł. In: System Prawa Prywatnego. Prawo Prywatne Międzynarodowe, ed. M. Pazdan, vol. 20B.

Żarnowiec Ł., Prawo właściwe dla odpowiedzialności z tytułu culpa in contrahendo na podstawie przepisów rozporządzenia Parlamentu Europejskiej i Rady (WE) - Rzym II, Europejski Przegląd Sądowy 2010, vol. 2. 
